\title{
Effect of Homa organic farming on growth, yield and quality parameters of Okra
}

\author{
Rajeev Kumar ${ }^{*}$, Adyant Kumar², Soumyabrata Chakraborty ${ }^{3}$ and P.W. Basarkar ${ }^{1}$ \\ ${ }^{1}$ Department of Biochemistry, University of Agricultural Sciences, Dharwad - 580005 (Karnataka), INDIA \\ ${ }^{2}$ Department of Agronomy, Bidhan Chandra Krishi Viswavidyalaya, Mohanpur-741252 (West Bengal), INDIA \\ ${ }^{3}$ Department of Agricultural Chemistry and Soil Science, Bidhan Chandra Krishi Viswavidyalaya, Mohanpur- \\ 741252 (West Bengal), INDIA \\ *Corresponding author. E-mail: rajeevbiochem58@rediffmail.com
}

Received: December 27, 2016; Revised received: May 3, 2017; Accepted: October 7, 2017

\begin{abstract}
A field experiment was conducted during kharif season of 2012 to study the biochemical efficacy of Homa organic farming practices in okra (Abelomoschus esculentus var. Arka Anamika) and laid out in randomized block design with 18 treatments replicated thrice. The treatments consist of control treatments i.e. conventional control and homa control; homa treatments (Agnihotra and Om Tryambakam homa) and non-homa treatments; and liquid organic manures viz, Panchagavya, Jeevamruta and Gloria Biosol for soil and foliar application. Among the control treatments, organic control recorded highest growth, yield and quality parameters than other controls. Soil and foliar application of Gloria Biosol was significantly superior over all the treatments in terms of growth, yield and quality attributes and recorded $20.28 \%$ more plant height and $21.41 \%$ more yield than organic control treatments. Ascorbic acid and free total phenol content of okra fruits in homa treatments were also significantly superior over all the treatments and recorded $15.45 \%$ and $5.33 \%$ more over organic control, respectively. Thus, it may be recommended that soil and foliar application of Gloria Biosol, among all the Homa organic treatments, will give the better crop productivity and its produce quality.
\end{abstract}

Keywords: Agnihotra homa, Gloria Biosol, Jeevamruta, Okra, Om Tryambakam homa, Panchagavya

\section{INTRODUCTION}

Okra (Abelomoschus esculentus L. Moench) belongs to family Malvaceae and is cultivated for its fibrous fruits or pods containing white round seeds. Okra provides an important source of vitamins, calcium, potassium, iodine and other mineral matters which are often lacking in the diet of developing countries (Anonymous, 1990). India ranks first in the world with 3.5 million tonnes $(70 \%$ of the total world production) of okra produced from over 0.35 million ha land with productivity of 9.72 tonnes per hectare, while in Karnataka it occupies an area of 0.02 million ha with production of 0.16 million tonnes and productivity of 8.75 tonnes per hectare (Anonymous, 2015). Indian agriculture has been passing through a very turbulent phase. The green revolution had raised farmers' hopes to such an extent that sky was the only limit for them. However, in the past six decades, the naked face of chemical agriculture stood exposed and the farmer has not only lost his credibility in the market but also his confidence. The present farming totally depends on use of chemical fertilizers, pesticides and growth regulators for enhancing crop productivity but it has led to several ill effects on soil and the environment. Therefore, to culminate the ill effects of modern agriculture, there is need of an ecologically sound, viable and sustainable farming system.

Homa organic farming is one of the aspects of organic agriculture and is an ancient Vedic farming technique. Homa replenishes the nutrients that pollution robs from our environment and is totally a revealed science. It is as old as creation and come from 'Vedas'; the ancient most body of knowledge known to man. Homa organic farming thus makes some interesting promises based on Vruksha Ayurveda which tells that atmosphere is the biggest single factor which contributes about 75 per cent nutrition to the plants (Johnson and Heschl, 2009). The performance of homa requires organic farming as a base which totally excludes the use of chemical fertilizers, herbicides, pesticides, plant growth regulators, livestock feed additives and genetic modified organisms (Kumari Namrata et al., 2012).

Considering the potential benefits of organic production and its compatibility with Homa organic farming approaches for enhancing the quality of food and environmental sustainability, the present study was conducted on okra crop with the objective to evaluate the effect of different homa technologies on growth, yield and quality parameters under agro-climatic condition of Karnataka, India. 


\section{MATERIALS AND METHODS}

A field experiment was conducted to study the response of Homa organic farming practices on growth, quality and yield of okra (var. Arka Anamika) duringkharif2012at C-block Farm, Institute of Organic Farming, University of Agricultural Sciences, Dharwad while D-block Farm, University of Agricultural Sciences, Dharwad was selected for control treatments which was $1 \mathrm{~km}$ away from the C-block to avoid the effect of Homa organics. The soils of both sites are mixed Red and Black soil, and homogeneous.The experiment was laid out in randomized block design replicated thrice with 18 treatments.

The treatment $\left(\mathrm{T}_{1}\right)$ contains compost and vermicompost $(50 \%$ each) as soil application + seed treatment with bio-fertilizers and was used as organic control. The treatment $T_{1}$ was given to all the plots from $T_{2}$ to $\mathrm{T}_{16}$ in C- block and $\mathrm{T}_{18}$ in D-block prior to sowing. The treatment $T_{17}$ was conventional control while $T_{18}$ was used as homa control and were maintained in $\mathrm{D}$ - block farm of UAS, Dharwad at a distance of approximately $1 \mathrm{~km}$ away from the homa site (C - block) to avoid influence of homa on the crop. Non-homa ash was made by collecting and burning of agricultural waste products and was stored in separate bag which was used as only soil application $\left(\mathrm{T}_{2}\right)$, foliar application alone $\left(\mathrm{T}_{7}\right)$ and both soil and foliar application $\left(\mathrm{T}_{13}\right)$.

The Agnihotra homa and Om Tryambakam homa were performed as per the standard procedure (Johnson and Heschl, 2009). The ash collected from daily performance of Agnihotra homa at sun rise and sun set and stored separately in earthen pots; which was used for soil application alone $\left(\mathrm{T}_{3}\right)$, foliar application alone $\left(\mathrm{T}_{8}\right)$, and both soil \& foliar application $\left(\mathrm{T}_{14}\right)$. Soil application of Jeevamruta and Agnihotra ash $\left(\mathrm{T}_{6}\right)$, foliar application of Panchagavya and Agnihotra ash $\left(\mathrm{T}_{11}\right)$. Om Tryambakam homa has no specific timing was performed for 3-4 hours daily while chanting the specific mantra and its ash was stored separately in earthen pots. Om Tryambakam homa ash was used for the both soil and foliar application $\left(\mathrm{T}_{16}\right)$. The rate of application of Non-homa, Agnihotra homa and Om Tryambakam homa ash was $41.5 \mathrm{~kg} \mathrm{ha}^{-1}$ each in soil and foliage treatment.

Gloria biosol, a bio-digester contains vermicompost $(80 \mathrm{~kg})$, fresh cow dung $(80 \mathrm{~kg})$, fresh cow urine $(10$ L), Agnihotra homa ash (250 g), Shree Yantram made of copper (1 unit) and water (200 L) and was incubated for 30 days in an air-tight plastic tank (Guzman, 2006). It was used for soil application alone $\left(\mathrm{T}_{4}\right)$, foliar application alone $\left(\mathrm{T}_{9}\right)$, foliar application of Panchagavya and Gloria Biosol $\left(\mathrm{T}_{12}\right)$ and both soil and foliar application $\left(T_{15}\right)$. The rate of application of Gloria biosol in soil and foliage treatment was $1850 \mathrm{~L} \mathrm{ha}^{-1}$.

Panchagavya, a liquid organic manure contains fresh cow dung $(7 \mathrm{~kg})$, cow urine (3 L), jaggery (250 g), ghee $(1 \mathrm{~kg})$, curd (2 L), milk (2 L), yeast (100 g), coconut water $(2 \mathrm{~L})$, ripened banana (12 piece) and water $(10 \mathrm{~L})$; was prepared and used for foliar application $\left(\mathrm{T}_{10}\right)$. While another liquid organic manure, Jeevamruta containing cow dung $(10 \mathrm{~kg})$, cow urine $(10 \mathrm{~L})$, jaggery $(2 \mathrm{~kg})$, coconut water $(2 \mathrm{~L})$, legume flour $(2 \mathrm{~kg})$ and water $(200 \mathrm{~L})$ was prepared and used for soil application $\left(\mathrm{T}_{5}\right)$. The rate of application of Panchagavya on foliage was $25 \mathrm{~L} \mathrm{ha}^{-1}$ while that of Jeevamruta was $500 \mathrm{~L} \mathrm{ha}^{-1}$ in the soil. All the treatments from $\mathrm{T}_{2}$ to $\mathrm{T}_{16}$ were imposed at sowing and after sowing of the seeds. The crop was sown on $2^{\text {nd }}$ June, 2012 with a seed rate of $12 \mathrm{~kg} \mathrm{ha}^{-1}$ as line sowing in $45 \mathrm{~cm} \times 30 \mathrm{~cm}$ spacing. The fertilization of the crop was done according to the treatments and the crop was grown with the standard package of practices for the region.

Observation on growth and yield parameters: Five plants were selected randomly and tagged from each experimental plot and these plants were used to record the growth and yield observations. Growth observations include plant height, number of branches per plant, number of leaves and leaf area while yield observations were 100-fruit weight and fruit yield.

Observation on quality parameters: For the plant analysis, okra samples were analyzed separately for their nitrogen, phosphorus, potassium and micronutrient at harvest stage. The quality parameters recorded were ascorbic acid (AOAC, 1960), phenol content (Singleton et al. 1999) and macro-nutrients (N, P and $\mathrm{K})$ as well as micro-nutrients $(\mathrm{Cu}, \mathrm{Zn}, \mathrm{Mn}$ and $\mathrm{Fe})$ as suggested by Jackson, 1973.

Statistical analysis: The data recorded for each parameter of the experiment were analyzed statistically applying "Analysis of variance" technique. Overall differences were tested by " $F$ " test of significance at 5 per cent level of significance as suggested by Gomez and Gomez (1984).

\section{RESULTS AND DISCUSSION}

Growth parameters: All the treatments significantly recorded the highest plant height over both (conventional, homa and organic) control (Table 2). The treatment $\mathrm{T}_{15}\left(\mathrm{~T}_{1}+\right.$ Soil application of Gloria Biosol 1850 liters $\mathrm{ha}^{-1}$ and its foliar application at 30, 45, 60 and 75 DAS) recorded highest plant height $(88.06$ $\mathrm{cm}$ ) which was $135.27 \%, 127.24 \%$ and $120.28 \%$ more over conventional, homa and organic control, respectively; and was at par with the soil and foliar application of $\mathrm{T}_{16}\left(\mathrm{Om}\right.$ Tryambakam ash), $\mathrm{T}_{14}$ (Agnihotra ash) and $\mathrm{T}_{13}$ (non-homa ash) and was also found significant over rest of the treatments. The treatment $T_{16}$ (soil and foliar application of Om Tryambakam ash) recorded $129.19 \%, 121.51 \%$ and $114.88 \%$ while Agnihotra ash $\left[\mathrm{T}_{14}\right]$ recorded $127.68 \%, 120.10 \%$ and $113.54 \%$ and Non-homa ash $\left[\mathrm{T}_{13}\right] 124.78 \%, 117.37 \%$ and $110.95 \%$ more plant height over all the three controls in similar manner. Application of homa organic input might be 
Table 1. Growth and Yield parameters of Okra (var.ArkaAnamika) as influenced by different treatments.

\begin{tabular}{|c|c|c|c|c|c|c|c|}
\hline \multicolumn{2}{|c|}{ Treatments } & \multirow{2}{*}{$\begin{array}{l}\begin{array}{l}\text { Plant } \\
\text { height } \\
\text { (cm) }\end{array} \\
73.21\end{array}$} & \multirow{2}{*}{$\begin{array}{l}\begin{array}{l}\text { Num- } \\
\text { ber of } \\
\text { leaves }\end{array} \\
14.92\end{array}$} & \multirow{2}{*}{$\begin{array}{l}\begin{array}{l}\text { Leaf area } \\
\left(\mathbf{c m}^{2}\right. \\
\left.\text { plant }^{-1}\right)\end{array} \\
391.69\end{array}$} & \multirow{2}{*}{$\begin{array}{l}\begin{array}{l}\text { Number } \\
\text { of } \\
\text { Branches }\end{array} \\
5.13\end{array}$} & \multirow{2}{*}{$\begin{array}{l}\begin{array}{l}\text { Yield } \\
\left(\mathbf{t ~ h a}^{-1}\right)\end{array} \\
12.38\end{array}$} & \multirow{2}{*}{$\begin{array}{l}\begin{array}{l}\text { 100-fruit } \\
\text { weight } \\
\text { (kg) }\end{array} \\
1.22\end{array}$} \\
\hline $\mathrm{T}_{1}$ & $\begin{array}{l}\text { Organics equivalent to RDF (compost and ver- } \\
\text { micompost, } 50 \% \text { each) and seed treatment with } \\
\text { bio-fertilizers (organic control) at homa site }\end{array}$ & & & & & & \\
\hline $\mathrm{T}_{2}$ & $\begin{array}{l}\mathrm{T}_{1}+\text { soil application of Non-homa ash }((41.5 \mathrm{Kg} / \\
\text { ha) }) \text { at sowing, 30, } 45 \text { and } 60 \mathrm{DAS}\end{array}$ & 73.62 & 15.98 & 394.32 & 5.30 & 12.94 & 1.46 \\
\hline $\mathrm{T}_{3}$ & $\begin{array}{l}\mathrm{T}_{1}+\text { soil application of Agnihotra homa ash } \\
(41.5 \mathrm{Kg} / \mathrm{ha}) \text { at sowing, } 30,45 \text { and } 60 \mathrm{DAS}\end{array}$ & 77.12 & 17.01 & 400.31 & 5.36 & 13.95 & 1.54 \\
\hline $\mathrm{T}_{4}$ & $\begin{array}{l}\mathrm{T}_{1}+\text { soil application of Gloria Biosol (1850 } \\
\text { liters/ha) at sowing, } 30,45 \text { and } 60 \mathrm{DAS}\end{array}$ & 78.39 & 19.21 & 403.62 & 5.41 & 14.21 & 1.61 \\
\hline $\mathrm{T}_{5}$ & $\begin{array}{l}\mathrm{T}_{1}+\text { soil application of Jeevamruta (500 liters/ } \\
\text { ha) at sowing, 30, } 45 \text { and } 60 \text { DAS }\end{array}$ & 76.20 & 16.53 & 400.91 & 5.36 & 14.01 & 1.46 \\
\hline $\mathrm{T}_{6}$ & $\begin{array}{l}\mathrm{T}_{1}+\text { soil application of Jeevamruta }(500 \text { liters/ } \\
\text { ha) and Agnihotra homa ash }(41.5 \mathrm{Kg} / \mathrm{ha}) \text { at } \\
\text { sowing, } 30,45 \text { and } 60 \mathrm{DAS}\end{array}$ & 78.91 & 19.51 & 408.21 & 5.42 & 14.52 & 1.65 \\
\hline $\mathrm{T}_{7}$ & $\begin{array}{l}\mathrm{T}_{1}+\text { Foliar application of Non-homa ash } \\
(41.5 \mathrm{Kg} / \mathrm{ha}) \text { at } 30,45,60 \text { and } 75 \mathrm{DAS}\end{array}$ & 73.50 & 14.95 & 393.59 & 5.27 & 12.32 & 1.33 \\
\hline $\mathrm{T}_{8}$ & $\begin{array}{l}\mathrm{T}_{1}+\text { Foliar application of Agnihotra homa ash } \\
(41.5 \mathrm{Kg} / \mathrm{ha}) \text { at } 30,45,60 \text { and } 75 \text { DAS }\end{array}$ & 76.02 & 15.01 & 393.63 & 5.34 & 12.97 & 1.36 \\
\hline $\mathrm{T}_{9}$ & $\begin{array}{l}\mathrm{T}_{1}+\text { Foliar application of Gloria Biosol (1850 } \\
\text { liters/ha) at } 30,45,60 \text { and } 75 \mathrm{DAS}\end{array}$ & 77.08 & 16.36 & 398.31 & 5.39 & 13.35 & 1.38 \\
\hline $\mathrm{T}_{10}$ & $\begin{array}{l}\mathrm{T}_{1}+\text { Foliar application of Panchagavya }(5 \%) \text { at } \\
30,45,60 \text { and } 75 \text { DAS }\end{array}$ & 76.05 & 16.39 & 396.36 & 5.33 & 13.20 & 1.37 \\
\hline $\mathrm{T}_{11}$ & $\begin{array}{l}\mathrm{T}_{1}+\text { Foliar application of Panchagavya }(5 \%) \text { and } \\
\text { Agnihotra homa ash }(41.5 \mathrm{Kg} / \text { ha) at } 30,45,60 \\
\text { and } 75 \mathrm{DAS}(41.5 \mathrm{Kg} / \mathrm{ha}) \\
\mathrm{T}_{1}+\text { Foliar application of Panchagavya }(5 \%) \text { and }\end{array}$ & 77.01 & 16.26 & 398.29 & 5.37 & 13.30 & 1.40 \\
\hline $\mathrm{T}_{12}$ & $\begin{array}{l}\text { GloriaBiosol (1850 liters/ha) at 30, 45, } 60 \text { and } \\
75 \text { DAS }\end{array}$ & 77.06 & 16.38 & 398.87 & 5.39 & 13.27 & 1.43 \\
\hline $\mathrm{T}_{13}$ & $\begin{array}{l}\mathrm{T}_{1}+\text { Soil application of Non-homa ash }(41.5 \mathrm{Kg} / \\
\text { ha) and its foliar application at } 30,45,60 \text { and } 75 \\
\text { DAS }\end{array}$ & 81.23 & 19.83 & 419.72 & 6.41 & 14.73 & 2.25 \\
\hline $\mathrm{T}_{14}$ & $\begin{array}{l}\mathrm{T}_{1}+\text { Soil application of Agnihotra homa ash } \\
(41.5 \mathrm{Kg} / \mathrm{ha}) \text { and its foliar application at } 30,45 \text {, } \\
60 \text { and } 75 \mathrm{DAS}\end{array}$ & 83.12 & 20.56 & 421.21 & 6.92 & 14.80 & 2.32 \\
\hline $\mathrm{T}_{15}$ & $\begin{array}{l}\mathrm{T}_{1}+\text { Soil application of Gloria Biosol }(1850 \\
\text { liters/ha) and its foliar application at } 30,45,60 \\
\text { and } 75 \text { DAS }\end{array}$ & 88.06 & 22.31 & 428.56 & 8.03 & 15.03 & 2.43 \\
\hline $\mathrm{T}_{16}$ & $\begin{array}{l}\mathrm{T}_{1}+\text { Soil application of OmTryambakam homa } \\
\text { ash }(41.5 \mathrm{Kg} / \mathrm{ha}) \text { and its foliar application at } 30 \text {, } \\
45,60 \text { and } 75 \mathrm{DAS}\end{array}$ & 84.10 & 21.03 & 423.76 & 7.93 & 14.91 & 2.36 \\
\hline $\mathrm{T}_{17}$ & Conventional control at non-homa site & 65.10 & 13.61 & 388.13 & 3.96 & 11.02 & 1.01 \\
\hline $\mathrm{T}_{18}$ & $\begin{array}{l}\text { Organics equivalent to RDF (compost and ver- } \\
\text { micompost, } 50 \% \text { each) and seed treatment with } \\
\text { bio-fertilizers (organic control) at non- homa } \\
\text { site }\end{array}$ & 69.21 & 13.95 & 389.93 & 4.10 & 11.76 & 1.16 \\
\hline SEn & & 2.41 & 0.92 & 3.72 & 0.5 & 0.12 & 0.10 \\
\hline $\mathrm{CD}$ & $5 \%$ & 6.87 & 2.49 & 10.59 & 0.16 & 0.31 & 0.25 \\
\hline
\end{tabular}

accelerated the plant growth by assimilating more amount of essential nutrients which were made available through fertilization. The use of organic fertilizer would have increase the aeration, drainage and maintained favourable soil environment for deeper penetration of roots and optimum nutrient extraction from soil for the utilization of the plant (Thirunavukkarasu and Balaji 2015). The result on other growth parameters viz. number of branches, number of leaves and leaf area was also significantly highest with treatment $T_{15}$
[Soil and foliar application of Gloria Biosol] i.e., 8.03 branches, 22.31 leaves and $428.56 \mathrm{~cm}^{2}$ leaf area plant ${ }^{-1}$ and this was also followed by the soil and foliar application of $\mathrm{T}_{16}$ (Om Tryambakam ash), $\mathrm{T}_{14}$ (Agnihotra ash) and $\mathrm{T}_{13}$ (Non-homa ash). The increase in growth parameters of okra may be due to solubilisation effect of plant nutrients by the addition of compost, vermicompost and bio-fertilizers (Azotobacter and phosphate solubilizing bacteria) as seed treatment leading to increase uptake of NPK and also due to its favoura- 
Rajeev Kumar et al. / J. Appl. \& Nat. Sci. 9 (4): 2205 - 2210 (2017)

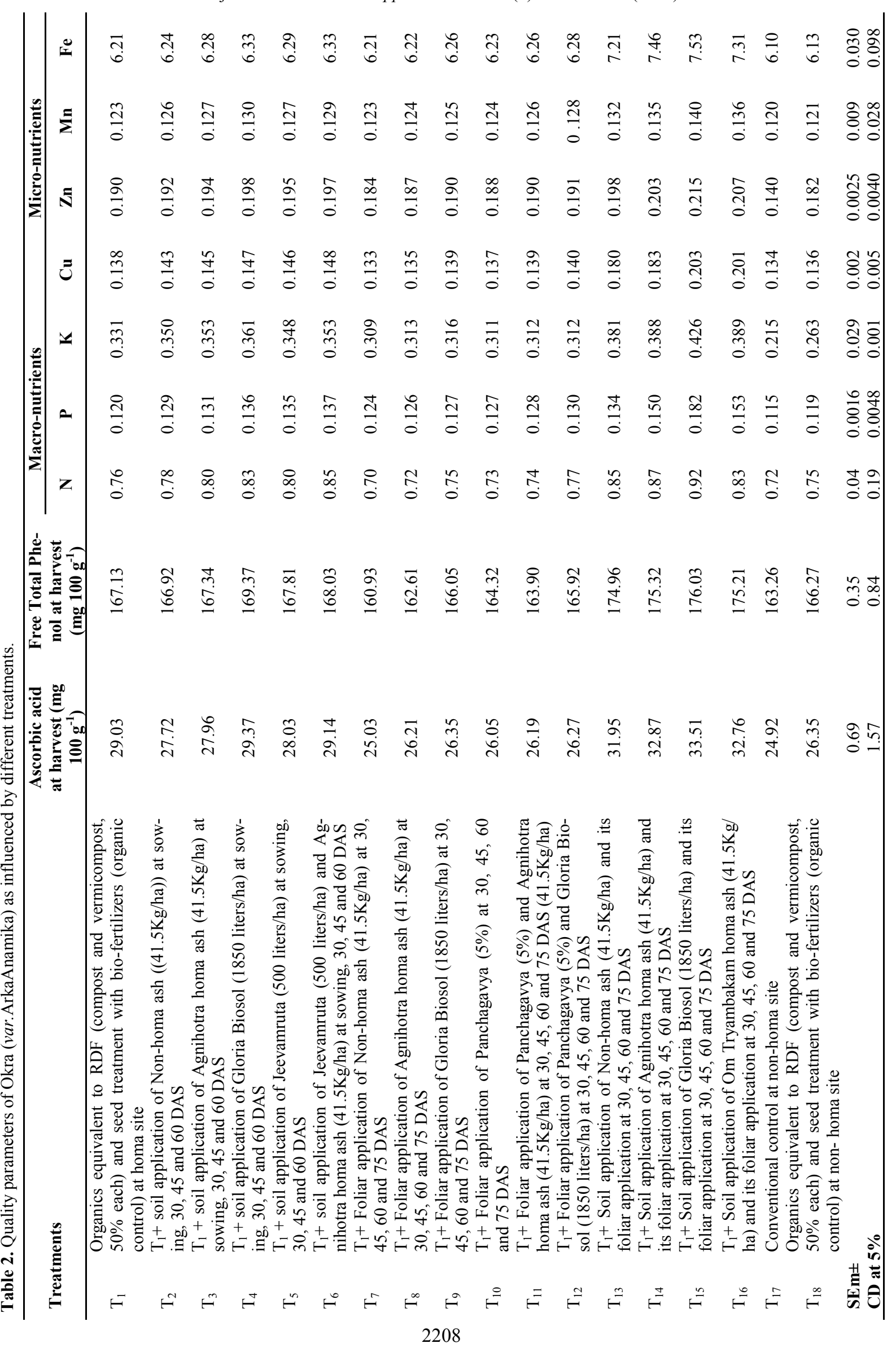


ble effect on several physical, chemical and biological properties of the soil. The application of soil amendment increases leaf area of the plant and this is the most important agronomical result of nutrient application, because an increase in leaf area results in improved radiation intercepted by the crop and therefore, leads to higher rate of photosynthesis (Maheswarappa et al., 1999).

Yield and yield parameters: The data on 100-fruit revealed that all the homa organic treatments significantly recorded the maximum 100 -fruit weight $(\mathrm{kg})$ and yield per hectare over conventional, homa and organic control (Table 2). The soil and foliar application of Gloria Biosol $\left(\mathrm{T}_{15}\right)$ registered 240.59\%, $209.48 \%$ and $199.18 \%$ increase in 100 -fruit weight; and $136.39 \%, 127.81 \%$ and $121.41 \%$ increase in yield per hectare over all the three controls i.e. conventional $\left(\mathrm{T}_{17}\right)$, homa $\left(\mathrm{T}_{18}\right)$ and organic $\left(\mathrm{T}_{1}\right)$ control. The result of treatments soil and foliar application of Om Tryambakam homa ash $\left(\mathrm{T}_{16}\right)$, Agnihotra ash $\left(\mathrm{T}_{14}\right)$ and nonhoma ash $\left(\mathrm{T}_{13}\right)$ was also found similar with the soil and foliar application of Gloria Biosol $\left(\mathrm{T}_{15}\right)$ and all these treatments were significantly superior over rest of the treatments. Among all the three control treatments, the yield obtained from organic $\left(\mathrm{T}_{1}\right)$, homa $\left(\mathrm{T}_{18}\right)$ and conventional $\left(\mathrm{T}_{18}\right)$ control differed significantly with each other. This indicates that creating homa atmosphere was a positive step to boost the production of healthy okra fruits significantly in an organic field. Many reports done by earlier workers support such an increase in the growth and yield of okra with organic sources of nutrients which might be due to the better nutrient availability and nutrient uptake by the crop (Sadat, 2000 and Akande et al., 2003).

Quality parameters: The result of quality parameters viz. ascorbic acid, total free phenols, macro as well as micro-nutrients [N, P, K, Cu, Zn, Mn and Fe] revealed that soil and foliar application of Gloria Biosol $\left(\mathrm{T}_{15}\right)$ differed significantly over conventional, homa and organic control and was at par with the soil and foliar application of $\mathrm{T}_{16}$ (Om Tryambakam ash), $\mathrm{T}_{14}$ (Agnihotra ash) and $\mathrm{T}_{13}$ (non-homa ash) and was also found significant over rest of the treatments. Among the control treatments, organic control at homa site resulted significant difference over both conventional and homa control treatments. Thus, the treatment soil and foliar application of Gloria Biosol recorded the highest content of ascorbic acid (27\%), total free phenols (5\%), N (21\%), P (52\%), K (29\%), Cu (47\%), Zn $(13 \%), \mathrm{Mn}(14 \%)$ and $\mathrm{Fe}(21 \%)$ were observed in harvested okra as compared to organic control when exposed to homa atmosphere. Increase in the quality parameters of okra observed in this investigation may be due to increased availability of major as well as minor nutrients, because major nutrients especially nitrogen and potassium play a vital role in enhancing the quality of crops by entering the protoplasm leading to en- hancement of the quality attributes viz. ascorbic acid, total free phenols, fruit colour, shelf life of the fruit, etc.

In case of macro- and micro-nutrients, this result showed that the novelty of organic sources lies in possessing macro nutrients ( $\mathrm{N}, \mathrm{P}$ and $\mathrm{K})$ as well as micro nutrients like $\mathrm{Zn}, \mathrm{Mn}, \mathrm{Cu}, \mathrm{Fe}$ etc. in respect to the conventional sources. This result has been reflected in the Table 2 which may be due increased macro- and micro -nutrient content of the soil as observed at homa site wherever homa treatments were imposed in the present investigation. The results are in conformity with Jadhav et al. (2001) who reported that organic sources are rich in macro- as well as micro-nutrients and they did not only enhance the nutrient status of the soil and consequently vegetative growth of the plants but also reduced the incidence of pests and diseases in the vegetable crops (Varela and Seif, 2004).

\section{Conclusion}

The present study demonstrates that Homa organic farming practices were better over organic treatments in terms of growth, yield and quality parameters and thus, not only provide the organic sources of nutrients but also take care of the health of soil, crop and its produce; lowers the incidence of pest and diseases as well as heals the atmosphere by preventing it from minimizing the use of chemical fertilizers which are toxic for human as well as plant and livestock health. All the Homa organic practices can be adopted to minimize the pollution of the environment and for maintaining the sustainability. But the use of Gloria Biosol in soil as well as foliar spray was found more effective in increasing the growth, yield and quality parameters than other Homa organic treatments. Soil and foliar application of Om Tryambakam homa ash, Agnihotra homa ash and Non-homa ash was also effective in context to Gloria Biosol.

\section{REFERENCES}

AOAC (1960). Methods of analysis. Association of Official Agriculture Chemicals, Washington D. C., Ninth Edition.

Akande, M.O., Oluwatoyinbo, F.I., Adediran, J.A., Buari, K.W. and Yusuf, I.O. (2003). Soil amendments affect the release of $\mathrm{P}$ from rock phosphate and the development and yield of okra. J. Veg. Crop Prod.9(2): 3-9.

Anonymous, (1990). International Board for Plant Genetic Resources IBPGR (1990), Report on International Workshop on Okra Genetic resources held at the National bureau for Plant Genetic Resources, New Delhi, India.

Anonymous, (2015). Area, Production and Productivity of Vegetable Crops, Horticulture at a Glance (2015), Ministry of Agriculture and Farmers Welfare, Govt. of India.

Gomez, K.A. and Gomez, A.A.(1984). Statistical Procedure for Agricultural Research, $2^{\text {nd }}$ edition, John Willey and Sons, New York. 
Guzman, G., 2006, Biosol, a novel bio-digester for use in agriculture. A bulletin of Fivefold Path Mission, Dhule, Maharashtra, India.

Jackson, M.L. (1973). Method of Soil Analysis, Agronomy Monograph No. 9, Part-II, American Society of Agronomy Inc., Publication, Madison, Wisconsin, USA.

Jadhav, S.V., Patil, G.M. and Lingappa, S. (2001). Combination effect of organic and inorganic manures on the quality of M-5 mulberry leaves. Karnataka $J$. Agril. Sci.14(2): 496-499.

Johnson, B. and Heschl, K.(2009). Homa organic farming, In: The proceedings of the 'Brain storming conference' on 'Bringing Homa Organic Farming in to the Main stream of Indian Agricultural system' held at Tapovan, Parola-Amalner Road, PAROLA, Dist.: Jalgaon, Maharashtra on 25-26 Feb, 2009, pp: 84-94.

Kumari Namrata, Basarkar, P.W., Babalad,H.B. and Sreenivasa, M.N. (2012). Yield and yield attributes and economics of soybean as influenced by homa organic farming practices.Karnataka J. Agric. Sci.25 (2): 270 272.

Maheswarappa, H.P., Nanjappa, H.V., Hegde, M.R. and Balu, S.R. (2009). Influence of planting material, plant population and organic manures on yield of East Indian Galangal and on soil physiochemical and biological properties. American-Eurasian Journal of Sustainable Agriculture.3(1): 6-8

Sadat, M.S.I. (2000). Studies on the effects of different levels of nitrogen, phosphorous and potassium on the growth yield and seed production of okra (AbelomoschusesculentusL.). M.Sc. Thesis, Dept. of Horticulture, Bangladesh Agril. Univ., Mymensingh, Bangladesh

Singleton, V.L., Orthofer, R. and Lamuela, R.M. (1999). Analysis of total phenols and other oxidation substrates and antioxidants by means of Folin-Ciocalteu reagent. Methods Enzymol. 299: 152-178

Thirunavukkarasu, M. and Balaji, T. (2015). Effect of Integrated nutrient management (INM) on growth attributes, biomass yield, secondary nutrient uptake and quality parameters of bhendi (Abelmoschus esculentus L.). Journal of Applied and Natural Science, 7 (1) : 165 169 (2015)

Varela, A.M. and Seif, A. (2004). A Guide to IPM and Hygiene Standards in Okra Production in Kenya. ICIPE, Kenya, ISBN: 9290641615 